\title{
Derleme/Review \\ Anaçların (Maternal) ve/veya Yumurta İçi (İn ovo) Antioksidan Beslemenin Kanatlılarda Gen Ekspresyonu ve Performans için Önemi
}

\author{
Mehmet Reşit KARAGEÇİLI, Filiz KARADAŞ * \\ Yüzüncü Y1l Üniversitesi, Ziraat Fakültesi, Zootekni Bölümü, Van, Türkiye \\ *e-posta: fkaradas@yyu.edu.tr; Tel: +90 (432) 22517 01; Faks: +90 (432) 2251104
}

\begin{abstract}
Özet: Günümüzde ticari kanatlı hayvanlara uygulanan yoğun seleksiyona bağlı olarak embriyoların metabolik hızının artmasıyla birlikte besin madde gereksinimleri de artmıştır. Bu değişen besin madde ihtiyacının karşılanmaması embriyonik gelişim, çıkış gücü, çıkış kalitesi ve çıkış sonrası performans gibi parametreler üzerinde olumsuz etkiye neden olmaktadır. Yumurta, embriyonal gelişim sırasında yoğun embriyonik metabolizmanın sebep olduğu oksidatif hasardan embriyoyu korumak amacıyla, maternal kökenli antioksidanları bol miktarda içermektedir. Damızlıkların (maternal) antioksidan ilaveli yemlerle beslenmesi veya damızlıklardan elde edilen yumurtaların kuluçka esnasında yumurta içi (in ovo) antioksidan beslenmesi ile deneysel olarak yumurtanın temel antioksidan içeriğinin değiştirilmesinin, embriyo ve civcivlerin antioksidan bileşenleri üzerine etkisinin olduğu, oksidatif stresin zararlı etkisinin azaldığı ve sonuçta çıkış sonrası civciv gelişiminin olumlu yönde etkilendiği yapılan çalışmalarla bildirilmiştir. Ayrıca maternal verimi artırmak ve çıkış sonrası civcivlerin yaşama gücünü iyileştirmek amacıyla anaçlar karmaşık epigenetik maternal etkinin bir parçası olarak antioksidanları yemden yumurtaya transfer ettikleri ileri sürülmektedir. Maternal ve in ovo antioksidan besleme ile embriyonun kritik dönemde ihtiyaç duyduğu antioksidan miktarının artırılması, embriyo dokularındaki antioksidan miktarını yükseltmekte, dolayısıyla embriyonun yaşama gücünü olumlu yönde etkilemekte, civciv çıkış ağırlı̆̆ında artış gözlenmekte, çıkış sonrası yem kullanımını ve verimi iyileştirmekte olduğu ileri sürülmektedir. Bu olumlu etkinin, embriyonun epigenetik etki ile eksprese olan gen sayısındaki artış ile ilişkili olduğu, bu nedenle de bu etkinin birden fazla kuşağı etkileyebileceğini ileri süren çalışmalar mevcuttur. Bu derlemede, kanatlı damızlık yemi ya da döllü yumurtalara in ovo besleme yolu ile antioksidan konsantrasyonu artırılmış embriyoların gen ekspresyon ilişkilerini inceleyen çalışmalar derlenmiştir.
\end{abstract}

Anahtar kelimeler: Antioksidanlar, Gen ekspresyonu, in ovo enjeksiyon, Maternal besleme

\section{The Importance of Maternal and/or In ovo Antioxidant Feeding for Gene Expression and Performance in Poultry}

\begin{abstract}
At the present time, the nutrient requirements were increased with increasing of embryo metabolic rate according as the intensive selection applied to commercial poultry. Failure to meet this changing nutrient requirement causes adverse effects on parameters such as embriyonic development, hatching power, hatching quality and post-hatching performance. Poultry eggs contain large amounts of maternally-derived antioxidants that protect the embryo from oxidative damage caused by intense embryonic metabolism. There are few experimentally (in ovo and maternally feeding) studies have tested the effects of experimental change in yolk concentration of a major antioxidant on other antioxidant content of egg yolk, embryo and post hatch chick survive, whether, oxidative stress were affected from manipulation of antioxidants or not, to compare effects of this on postnatal chick development. At the same time, it has been reported that to increase breeder's productivity and postnatal survival rate, breeders can transfer antioxidants from feed to egg as a part of complex epigenetic mechanism. Maternal and in ovo antioxidant feeding increase antioxidant level in the embryo tissues to be used by embryo in the critical period therefore it positively effects embryo viability, increases hatching weight and improves posthatching feed consumption and yield. This positive effect was related to increase of the number of expressing genes with epigenetic effects, due to previous studies were determined that this effect was continuing for a few generations. In this review, articles on gene expression relationship with increased antioxidant concentration of embryo via maternal feeding or in ovo feeding have been reviwed.
\end{abstract}

Keywords: Antioxidants, Gene expression, in ovo injection, Maternal nutrition 


\section{Giriş}

Civciv embriyoları, kuluçka sırasında ihtiyaç duydukları tüm besin maddelerini, yumurta akı ve sarısından karşılamaktadırlar. Kuluçka sırasında embriyo tarafından tamamen tüketilen yumurta akı, yumurtanın \%6575'ni oluşturmakta ve içeriği \%88 su ile \%12 proteinden oluşmaktadır (Romanoff 1960; Shenstone 1968). Yumurta sarısı ise $\% 50 \mathrm{su}, \% 15$ protein, \%33 yağ ve \%1'den daha az karbonhidrat içermektedir. Yumurta sarısının kimyasal komposizyonu büyük oranda yumurta ağırlığı, genetik yapı, anacın yaşı ve tükettiği yem miktarına göre değiştiğinden, çıkış sonrası civciv ve piliç performansını ve yaşama gücünü etkileyebilmektedir (Triyuwanta ve Nys 1992; Peebles ve ark. 1999; Lopez ve Leeson 1994; Hossain ve ark. 1998; Enting ve ark. 2007).

Anaç tarafından tüketilen makro (hormon, antikor ve protein gibi) ve mikro (karotenler) besin maddeleri öncelikle yumurta sarısında birikmekte ve kuluçka sırasında döllü yumurtada gelişen embriyonun dokularına transfer olmaktadır (Blount ve ark. 2000; 2002; Biard ve ark. 2007; Rubolini ve ark. 2016). Embriyo dokularında mevcut birikimin çıkış sonrası en az 2-4 hafta daha civcivi etkilediği saptanmıştır (Grindstaff ve ark. 2003; Karadas ve ark. 2006; Surai ve ark. 2006; Hasselquist ve Nilsson 2009).

Kuluçka sırasında besinler yumurta sarısından, yumurta sarısı zarı (Yolk Sac Membran, YSM) ve onu çevreleyen damarlar aracılığıyla embriyoya geçmektedir (Noble ve Cochi 1990). Embriyo, yumurta sarı kalıntısını (Yolk Sac Residual, YSR) inkübasyonun son günlerinde karın boşluğuna almaktadır (Noy ve Sklan 2001). Karın boşluğuna alınan YSR miktarına bağlı olarak civciv çıkış ağırlığının \%15-20'sini oluşturan YSR, (Romanoff 1960; Noble ve Ogunyemi 1989; Noy ve Sklan 2001) civcivlerin yeme ulaşıncaya kadar yedek besin deposu olarak kullanılmaktadır. Embriyo gelişimini önemli düzeyde etkileyen maternal besinler arasında en önemlilerinin lipid ve antioksidanlar oldukları ileri sürülmektedir (Surai 2002; Babacanoğlu ve Özkul Özelçam 2013). Ortalama 60 g ağırlığında bir yumurtanın 6 g’1 yani \%10’u lipidlerden oluşmaktadır. Yumurta sarısındaki toplam lipidlerin \%80’i embriyo gelişiminin son 7 gününde; embriyonik doku ve organlara mobilize olmakta ve embriyo gelişimi boyunca ihtiyaç duyulan enerjinin \%90’1 yăg asitlerinin oksidasyonundan sağlanmaktadır (Noble ve Cocchi 1990). Dolayısıly kanatlı embriyosunun gelişimi aerobik mekanizma ile sarıdaki yağ asidi zincirlerinin $\beta$-oksidasyonuna bağlıdır (Stock ve Metcalfe 1987; Noble ve Cocchi 1990). Oksijen tüketimi embriyonik dokuların gelişiminde gerekli olan besin maddelerinin sarıdan taşınmasını sağlayan enerji mekanizması için gereklidir.

Embriyonun oksijen tüketimi kuluçka süresinin orta döneminde ciddi bir artış göstermektedir. Kanatlı embriyolarında yüksek enerji metabolizması serbest radikallerin ve reaktif oksijen türlerinin üretilmesine öncülük ederek embriyo hücresinin makro moleküllerine zarar verebilmektedir (Halliwell 1994). Özellikle çoklu doymamış yağ asitleri serbest radikal kaynaklı oksidatif hasara karşı çok savunmasızdırlar (Porter ve ark. 1995) ve civciv embriyosunun çeşitli dokularındaki yağlar çoğunlukla doymamış özelliktedir (Noble ve Cocchi 1990; Maldjian ve ark. 1996). Bu nedenle civciv embriyosunu oksidatif hasara karş1 bir dizi antioksidan bileşik korumaktadır (Surai ve ark. 1996). Örneğin, vitamin E embriyo gelişimi sırasında yumurta sarısından embriyo dokularına taşınmakta ve lipid peroksidasyonunun zincir reaksiyonunu kırarak (Noble ve ark. 1993; Gaal ve ark. 1995; Surai ve ark. 1996) embriyoyu oksidatif hasarın zararlı etkilerinden korumaktadır.

Civciv kuluçkadan çıktıktan sonra da superoxide $\left(\mathrm{O}_{2} *\right)$, hidroksil $(* \mathrm{OH})$ ve peroksil (ROO*) gibi reaktif oksijen türlerinin (Halliwell ve Gutteridge 1999) yoğun saldırısıyla karşı karşıya kalmaktadır. Bu saldırıya karşı antioksidan sistemdeki enzimler aracılığı ile koruma sağlanmaktadır. Süperoksit dismutaz (SOD) enzimi, elektron taşıma zincirinde elektron sızması sonucu oluşan süperoksit radikalleri önce hidrojen perokside dönüştürmekte (Jaeschke 1995), ancak hala hücre için zararlı olan hidrojen peroksit, daha sonra katalaz (CAT) ve glutatyon peroksidaz (GSH-Px) enzimleri tarafından suya dönüştürülerek (Yu 1994) zararsız hale getirilmektedir. Böylece serbest radikallerin zararlı etkilerinden antioksidan savunma ile koruma sağlanmaktadır. Antioksidan savunma mekanizmasında en önemli korumayı GSH-Px, thioredoksin reduktaz (TrxR), iodothreonine derodinaz (ID) gibi seleno proteinlerin esansiyel bir parçası olan selenyum (Surai ve ark. 2016) elementi sağlamaktadır. Aynı şekilde, esansiyel aminoasit olan metiyonin ve lizin aminoasitlerinden sentezlenen L-karnitin (Bremer 1983), mitokondride, enerji üretmek amaciyla, uzun zincirli yağ asitlerinin beta-oksidasyonunda acil taşıyıcı olarak antioksidan savunmaya destek vermektedir. Aynı zamanda normal ve normal olmayan metabolizma olayları sırasında ortaya çıkan kısa ve orta zincirli yağ asitlerini de mitokondriden uzaklaştırma görevi yaparak lipid peroksitlerin oluşumunu da engellemektedir (Rebouche 1992). Metiyonin; L-karnitin sentezinde görev almakta, vücut, yumurta ve tüy 


\section{R. KARAGEÇİLİ, F. KARADAŞ}

proteinlerinin yapısını oluşturmaktadır (Pack 1996). Metiyonin amino asidinin antioksidan aktiviteye sahip olduğunu bildiren çalışmalar olmakla beraber (Saito ve ark. 2003; Sarmadi ve İsmail 2010) kanatlı beslemede bu amino asitlerin antioksidan aktivitelerini diğer antioksidanlar ile kıyaslayan çalışma yok denecek kadar azdır.

Vücutta metiyonin ve sistin aminoasitlerinden sentezlen taurin amino asidinin; oksijen reaktif ajanları (ROS) tutucu özelliği ile direkt antioksidan aktivite gösterdiği (Cozzi ve ark. 1995; Redmond ve ark. 1996), membran geçirgenliğini azaltarak hücreye oksidatif hasardan koruma sağlayıp indirekt antioksidan korumaya katkıda bulunduğunu gösteren çalışmalar mevcuttur (Banks ve ark. 1992; Geden ve ark. 1992). Suda çözünen antioksidan olan askorbik asit ise yumurta sarısı membranından sentezlenmekte ve başta beyin olmak üzere çeşitli dokulara taşınarak oksidatif hasardan embriyoyu korumaktadır (Wilson 1990; Surai ve ark. 1996). Kanatlllar vitamin C sentezleme yeteneğine sahiptirler (Sahin ve ark. 2003) ancak yüksek ve düşük çevre sıcaklı̆̆ı, nem, yüksek verim oranı ve parazit bulaşması gibi stress koşulları altında askorbik asit sentezinin yeterli olmadığı bildirilmiştir (Freeman 1967; Sykes 1979; McDowell 1989; Cheng ve ark. 1990). Görüldüğü gibi antioksidanlar, oksidatif hasarı önleme bakımından kanatlı beslemede yoğun araştırmalara konu olan bileşiklerdir. Bu derlemede, kanatlı beslemede antioksidanların işleyiş mekanizmaları hakkında bilgi verilerek kanatlılardaki antioksidan etkinliği artıracak yöntemler ve bu yöntemlerin epigenetik mekanizma üzerindeki etkileri irdelenmiştir.

\section{Yumurta İ̧̧i (İn ovo) Besleme}

In ovo besleme alanındaki çalışmalar 1970'li yıllarda başlamış (Balaban ve Hill 1971) olup son 10 yılda bu alanda pratiğe akatarılabilecek başarılar elde edilmiştir. Nitekim günümüzde etlik piliçlerin yaklaşık $\% 95$ 'i in ovo enjeksiyon ile aşılanmaktadır. İ ovo besleme, kuluçka döneminde (tavuk embriyolarında özellikle kuluçkanın 15-18. günlerinde) yumurtanın farklı bölgelerine (amniyon, sarı kese, hava boşluğu vs.) karbonhidrat, amino asit ve çeşitli protein içeriklerine sahip sıvı solüsyonların enjeksiyonu esasına dayanan, patentli (Uni ve Ferket 2003) biyoteknolojik bir uygulamadır. İ ovo yöntem; 1982 yılında marek (MD) aşısının etkinliğini saptamak amacı ile kullanılmış (Sharma ve Burmester 1982), daha sonra (Sharma ve ark. 1984; Zhang ve ark. 2011) MD aşılarının çıkışta civcive uygulanmasına karşılık, geç embriyo gelişim döneminde in-ovo uygulamasının immun sistemi erken uyararak, aşının daha etkin olduğunu saptamışlardır. Günümüzde kanatlı hayvan sektöründe, saatte $\geq 70.000$ yumurta başlıklı in ovo cihazlar kullanılarak, özellikle marek (MD) aşılamada vazgeçilmez bir uygulama olduğu görülmektedir. In ovo aşı uygulamalarının, in ovo besleme alanına uygulanması ilk kez 2002'de Uni tarafindan bilimsel olarak başlatılmıştır. Yumurta içi besleme tekniği uygulanan embriyolara yumurtadan çıkmadan önce besin madde takviyesinin, maternal besleme yöntemine göre hayvanın sindirim sistemi gelişimi üzerinde daha olumlu sonuçlar verdiği bildirilmektedir (Uni 2003). Çünkü civcivlerin embriyonal gelişimlerinin son dönemlerinde sindirim enzimlerinin aktif hale geldiği ve bu dönemde civcivlerin embriyonal amniyon sıvısını tükettikleri göz önüne alındığında, bu embriyo gelişim döneminde sıvı besin maddelerinin amniyon sıvısı içerisine ilave edilmesi, civcivin çıkış öncesi ve kuluçka sonrası gelişimini hızlandırdığı söylenmektedir (Uni ve Ferket 2003; Çiftci ve ark. 2011). İn ovo besleme ile embriyo gelişimi ve civcivlerin yumurtadan çıkabilme kabiliyetlerinin arttığı (Foye ve ark. 2006); sağlanan besinsel destekle, bağırsak emiliminin iyileştiği, çıkış sonrası erken dönemde hastalık ve ölüm oranlarının azaldığı, enterik antijenlere karşı immün cevabın iyileştiği, iskelet gelişim bozukluklarının önüne geçildiği ve başta göğüs eti miktarı olmak üzere kas gelişiminin arttığı (Uni 2003) saptanmıştır. Bu teknolojinin uygulamada; yeme ve suya geç geçişle meydana gelen verim kayıplarının azaltmasında, kuluçka çıkışından sonra uygulanan başlatma öncesi yem uygulamalarına alternatif ya da beraber uygulanmasıyla daha iyi sonuçların alınmasında yardımcı olabileceği düşünülmektedir (Çiftci ve ark. 2011).

\section{Epigenetik mekanizma}

Üretim etkinliğini artırmak için yapılan genetik seleksiyonlar, ticari kanatlı hayvanların fizyolojik yaşam çizelgesini önemli düzeyde değiştirmektedir. Kanatlı endüstrisi tarafindan benimsenen ve uygulanan bu yaklaşım genetik, biyoteknoloji ve gelişimsel biyolojideki yeni teknolojilerle gelecekte de devam edecektir. Akademik genetik otoriteler yüzyılı aşkın süredir Mendel'in temel konseptini izlemektedir ve bu konsept DNA'nın keşfi ve sekansı ile güçlendirilmiştir. Genetik, temel DNA sekansındaki bilgilerin gelecek jenerasyonlara aktarımını tanımlar. DNA sekans fragmentlerini kesin biyolojik özellikler ile ilişkilendiren moleküler biyoloji uzmanları mRNA düzenlenmesi sırasında oluşan gen ekspresyonu üzerinde çalışmaya başlamıştır. Şimdilerde moleküler biyologlar gelecek nesillere aktarılan çevresel etmenlerin sonucu oluşan 
gen ekspresyonu üzerinde düşünmektedirler. Damızlıkların ve onların harfi harfine programlanacağı perinatal dönemdeki projenilerinin yem ve çevre faktörlerine genlerin nasıl adapte olduğunu gösteren kanıtlar her geçen gün artarak devam etmektedir. Bu gen ekspresyon programı artık bilim adamları tarafından "Epigenetik" olarak adlandırılmaktadır (Ferket 2012). Epigenetik, temel DNA diziliminde değişim olmaksızın, gen ekspresyonu ve diğer genomik fonksiyonlarda oluşan kalıtsal değişiklikleri gösteren genetiğin yeni bir alanıdır. Epigenetik, projeninin hayatında, büyüme performansını etkileyen maternal kökenli gen ekspresyonunu ifade etmektedir. Canlı organizma üzerinde bilinen veya tahmin edilen epigenetik etmenler: temel besin maddeleri, egzoz gazları, ağır metaller, hormonlar, sigara dumanı, radyoaktif maddeler, virüs, bakteri ve polisiklikaromatik hidrokarbonlardır (Weinhold 2006; Ferket 2012). Bunlar içerisinde yem en önemli epigenetik etmendir. Çünkü, organizma yaşamı boyunca yemle etkileşim halindedir. Ayrıca, yem kökenli metil vericiler (Metiyonin, L-karnitin, betain, taurin vb.) ve kofaktörler, CpG (Sitozin-Fosfat-Guanin) metilasyonu için gerekli olan S-adenozil metiyonin sentezini sağlamaktadır (Waterland ve Jirtle 2003).

Beslemenin epigenetik üzerindeki etkisi ikinci dünya savaşından sonra jenerasyonlarda görülen farklılıklardan yola çıkılarak araştırılmaya başlanmıştır. İkinci dünya savaşı sırasında Nazi askerleri çiftçilerin ürettiği yiyeceklerin neredeyse tamamına el koymuş çiftçilere zar zor yetecek kadar çok az yiyecek bırakmışlardır. Savaşın sonlarına doğru alışılmadık sert kışlar, savaştan zarar görmüş tarım alanlarından dolayı kıt yiyecek üretimi ve yiyecek ambargosu nedeniyle 30.000'den fazla Nazi insanın ölümüne neden olan ulusal kitlık baş göstermiştir. Bu dönemde (Dutch Winter Famine) tutulan detaylı doğum kayıtları bilim insanlarına oldukça yararlı veri sağlamıştır (Ferket 2012). Kıtlığa maruz kalan Hollandalı hamile Yahudilerin çocuklarında ve 3 jenerasyon sonrasındaki torunlarında düşük doğum ağırlığı, kısa vücut uzunluğu, diyabet, obezite, koroner kalp hastalıkları ve kanser gibi gelişimsel ve yetişkin dönem bozuklukları alışılmadık derecede yüksek oranda gerçekleşmiştir (Pray 2004). Bir başka çalışmada Kaati ve ark. (2002) ergenlik öncesi dönemde yiyecek tüketimi ile diyabet ve kalp hastalıkları arasında bağlantı kurmuşlardır. Hamile bir kadının diyetinin onun gen ekspresyonunu etkileyeceği gibi sadece onun çocuğunda değil torununda ve muhtemelen torununun çocuğunda da aynı sağlık problemlerine neden olabilecek gen ekspresyonlarına gidebileceği vurgulanmıştır.

Ferket (2012)'e göre; epigenetik etki iki kritik dönemde meydana gelebilmektedir;

1. Gametogenesis sırasında; her bir ebeveynden sağlanan metilleşmiş genler ile embriyo oluşum aşamasındaki epigenetik program (maternal epigenetik etki),

2. Embriyo çıkış öncesi amniyon sıvıyı tükettiği zaman meydana gelen epigenetik etkidir (in ovo enjeksiyon etkisi).

Epigenetik mekanizmanın en iyi anlaşılan türü metilasyondur (Weaver 2007). Kimyasal bir bileşiğe metil grubunun $\left(\mathrm{CH}_{3}\right)$ eklenmesine metilasyon denir. Kimyasal bir reaksiyon olan metilasyon biyolojik sistemlerde gerçekleşmektedir ve gen ifadesi, protein işlevlerinin denetiminde, ağır metallerin değişiminde ve RNA metabolizmasında rol oynamaktadır. Organizmada metilasyon, DNA metilasyonu ve protein metilasyonu olmak üzere iki şekilde gerçekleşmektedir (İzmirli ve ark. 2012). DNA metilasyonu gen düzenlenmesinde kritik epigenetik rol oynamaktadır (Friso ve ark. 2002). Bir karbon metabolizması yoluyla oluşan DNA metilasyonu en yaygın çalışılan epigenetik modifikasyondur. Ayrıca DNA metilasyonu birkaç enzime ve yemdeki metiyonin, folat, betain, kolin vb. besin maddelerine bağlıdır (Anderson ve ark. 2012).

Coşkun ve ark. (2014) etlik piliç yumurtalarına in ovo enjeksiyon ile $50 \mu 1$ DL-metiyonin ilave ettikleri çalışmada, çıkış gücünü, kontrol grubunda \%90.29, DL-metiyonin grubunda \%84.74, oransal civciv ağırlığı (çıkıştaki civciv ağırlığının başlangıç yumurta ağırlığına oranı) kontrol grubunda \%70.04, DL-metiyonin grubunda \%72.70 olarak saptamışlardır ve bu farkların önemli olduğunu bildirmişlerdir. Wang ve ark. (2009) misır-soya temelli Japon bildırcin civciv yemlerinde \%0.01 ve 0.05 taurin kullanımının immun cevabı ve büyüme performansını olumlu yönde etkilediğini saptamışlardır.

Macalintal (2012) in ovo selenyum (Se) enjeksiyonu yaptığı çalışmada yumurta başına $60 \mu \mathrm{g}$ kadar Se uygulanmasının embriyonun yaşam gücü üzerinde olumsuz bir etkisinin olmadığını bildirmiştir. Ayrıca Se enjeksiyonunun, kuluçkanın 20. gününde kalp, göğüs, akciğer ve karaciğerde Se miktarını artırdığı gözlenmiştir.

Chen ve ark. (2016) yaptıkları çalışmada etlik piliç diyetlerine Se zengin Saccharomyces cerevisiae (SSC) kaynağından $0.15,0.5$ ve $1.5 \mathrm{mg} / \mathrm{kg}$ Se ve sodyum selenit (SS) kaynağından $0.15 \mathrm{mg} / \mathrm{kg}$ Se ilave etmişlerdir. Yapılan bu çalışmada SSC ve SS ilavesi karaciğerde GPx-1'in (glutatyon peroksidaz 1) mRNA 


\section{R. KARAGEÇİLİ, F. KARADAŞ}

seviyesini 7. 14. ve 21. günlerde önemli derecede artırmıștır. 7. günde GPx-1 mRNA seviyesi SSC kaynaklı $0.15 \mathrm{mg} / \mathrm{kg}$ Se ilavesi olan grupta diğer Se gruplarına göre önemli ölçüde daha düşük seviyede gerçekleşmiştir. 14. ve 21. günlerde GPx-1'in mRNA seviyesi $0.5 \mathrm{mg} / \mathrm{kg}$ Se ilaveli grupta diğer $\mathrm{Se}$ gruplarına göre önemli ölçüde daha yüksek olduğunu bildirmişlerdir.

L-karnitin ile yapılan in ovo çalışmada $0,4,8$ ve $12 \mathrm{mg}$ L-karnitin-salin çözeltisi döllü broiler yumurtalarına enjekte edilmiştir (Rabie ve ark. 2015). Yapılan bu çalışmada çıkış gücü ve çıkış ağırlığı bakımından gruplar arası farkların önemsiz olduğu fakat çıkıştan sonraki 2. haftadan 7 . haftaya kadar 12 mg L-karnitin enjeksiyonu yapılan grubun diğer gruplara göre önemli ölçüde daha yüksek canlı ağırlığa sahip oldukları bildirilmiştir.

Oso ve ark. (2014) ile Al-Daraji ve Tahir (2014) tarafindan yapılan in ovo L-karnitin uygulamalarında kuluçka randımanı pozitif olarak etkilenmiştir.

Miguel-Carrasco ve ark. (2010) karnitinin antioksidan enzim genlerinin ekspresyonu üzerine etkilerini inceledikleri çalışmalarında, rat yemlerine $300 \mathrm{mg} / \mathrm{kg} /$ gün L-karnitin ilavesi yapmışlardır. Karnitin ilavesinin kalpte GSH-Px ve SOD ekspresyonunu önemli derecede düşürdüğünü, ayrıca karnitin muamelesinin da düşük eNOS (endothelial nitric oxide synthase) ve daha yüksek p22 phox (NADPH oxidase subunit p22 phox) ekspresyonuna neden olduğunu bildirmişlerdir.

Damızlık yemlerine vitamin E ilavesinin; yumurta verimi, civciv büyüme ve bağışıklık sistemi üzerine etkisinin in ovo enjeksiyon ile kıyaslandığı bir çalışmada (Hossain ve ark. 1998); 25, 50, 75 ve $100 \mathrm{mg} / \mathrm{kg}$ vitamin E ilave edilmiş yemler ile 24 haftalık yaştaki anaçlar 54 haftalık yaşa kadar (30 hafta boyunca) beslenmiştir. 40 haftalık yaşta $25 \mathrm{mg} / \mathrm{kg}$ vitamin E ile beslenen damızlık grubu yumurtalarına ayrıca $0,2.5$ ve $5 \mathrm{mg}$ her bir yumurtaya vitamin enjekte edilmiştir. Yumurta verimi, yumurta ağırlı̆̆ı, kuluçka randımanı, kuluçka çıkışı civciv ağırlığı ve performansı vitamin E ilave edilmiş damızlık yemlerinden etkilenmemiştir. Yumurta vitamin E içeriği $75 \mathrm{mg} / \mathrm{kg}$ 'a kadar önemli ölçüde artış göstermiştir. Maternal vitamin E katkılı ve in ovo Vitamin E enjeksiyonlu yumurtalardan çıkan civcivlerin NDV'ye (newcastle hastalığı) karşı immuniteyi arttırdığı ancak in ovo uygulamanın daha etkili olduğu, 42.gün CA (canlı ağırlık), yem değerlendirme oranı (YDO) ve ölüm oranlarının da vitamin E enjeksiyon yapılan gruplarda yem katkısına göre önemli düzeyde olumlu etkilendiği saptanmıştır.

Selim ve ark. (2012) Moskova ördek yumurtalarına askorbik asit ve vitamin E enjeksiyonu uyguladıkları çalı̧̧ada, enjeksiyon yapılmayan kontrol grubuna göre; önemli düzeyde çıkışta daha yüksek canlı ağıllık, daha yüksek final ağırlığı ve daha iyi YDO elde etmişlerdir.

Pierce ve ark. (2016) soya-mısır temelli etlik piliç yemlerine selenit kaynaklı Se, vitamin E ve Economase (EcoE) ilave ederek yaptıkları çalışmada diyetlere $0.3 \mathrm{ppm} \mathrm{Se}, 0.3 \mathrm{ppm} \mathrm{Se}+50 \mathrm{ppm}$ vitamin E, $0.3 \mathrm{ppm}$ $\mathrm{Se}+100 \mathrm{ppm}$ vitamin E ve $200 \mathrm{~g} /$ ton EcoE ilave etmişlerdir. Göğüs kasında kontrol grubuna E100 grubunda 312 transkriptin ekspresyon seviyesi değmiştir (179'u yukarı yönlü düzenlenmiş, 133'ü aşağı yönlü düzenlenmiştir). Antioksidan stres (HMOX2, PP3CA, PRDX6), lipid metabolizması (SCP2) ve bağışıklık sistemi (IFNGR2) ile ilişkili vitamin E'ye duyarlı genlerde yüksek vitamin E ve EcoE grubunda benzer değişimlerin görüldüğü bildirilmiştir.

Nowaczewski ve ark. (2012) Pekin ördek yumurtalarına kuluçkanın farklı günlerinde farklı dozlarda in ovo vitamin $C$ uygulaması yaptıkları çalışmada, döllü yumurtalardan en yüksek çıkış oranının \%74.6 ile kuluçkanın 20. günü $8 \mathrm{mg}$ vitamin C enjeksiyonu grubunda olduğu ve bu farkın kontrol grubuna (\%37.4) göre önemli olduğu sonucuna varmışlardır.

Sahin ve ark. (2009) sıcaklık stresindeki dişi bıldırcın yemlerine vitamin C ve E takviyesinin HSP70 (heat shock protein 70) geni üzerindeki etkileri araşıırdıkları çalışmalarında, sıcaklık stresi altındaki hayvanlara vitamin C ve E uygulamasının beyin ve yumurtalıktaki HSP70 gen ekspresyonunu oldukça önemli düzeyde düşürdüğünü fakat normal sıcaklık altındaki hayvanlarda etkisinin olmadığını raporlamışlardır.

Maternal ve yumurta içi besleme ile yumurtanın antioksidan içeriğinin zenginleştirilmesi, immun sistem etkinliğini ve dokularlardaki antioksidan miktarını artırmakta, kuluçka randımanı, çıkış gücü, ölüm oranı, final canlı ağırlığı, YDO, verim ve performansı değiştirmemiş veya olumlu etkileyerek canlının fizyolojik 
yaşam döngüsüne katkı sağlamış ve kaliteyi artırmıştır. Ayrıca bu yöntemlerle ile ilave edilen antioksidan bileşik ilgili genlerdeki gen transkriptini değiştirerek yeniden düzenlenmesini sağlamıştır.

\section{Sonuc}

Yumurtanın içerdiği besin maddeleri embriyonun tek besin kaynağıdır. Gerek embriyonal gelişim sırasında embriyonun daha iyi gelişmesine katkıda bulunmak gerekse de civciv döneminde henüz gelişmeye başlayan ve bu nedenle yemleri değerlendirme kapasitesi sınırlı olan civciv dokularında, ihtiyaç duyulan esansiyel besin madde miktarını artıracak etkili yöntemler (in ovo ve maternal besleme) ile yumurtanın besin madde komposizyonunun değiştirilmesinin, epigenetik mekanizma üzerine etkili olabileceği düşünülmektedir. Ticari kanatlı yetiştiriciliğinde projeni üzerine damızlı yetiştirme ve beslemenin etkilerini inceleyen çok az araştırma mevcut olup bu alanda bilimsel çalışmalar henüz yeni başlamıştır (Ashwell 2012). Maternal ve in ovo beslemeyi ayrı ayrı konu edinen çalışmalar son 5-10 yılda yoğunluk kazanmıştır. Ancak bu iki besleme tekniğinin birlikte kıyaslandığı çalışmalar yok denecek kadar azdır.

Sonuç olarak maternal ve in ovo antioksidan besleme ile

1. Yumurtayı farklı antioksidanlarca zenginleştirerek total antioksidan kapasitesini iyileştirme, oksidatif stres durumunu azaltma,

2. Embriyo ve civciv dokularında total antioksidan aktivite, antioksidan enzim ve eksprese olan gen (GSH-Px) seviyelerini artırma, embriyo ve civciv dokularında oksidatif stresi (MDA) azaltma,

3. Embriyo ve civciv ölümlerini azaltarak, kuluçka randımanını artırma,

4. Civcivlerin canlı ă̆ırlığını, yaşama gücünü ve yemden yararlanmayı iyileştirme,

5. Civciv dokularında yararlı besin madde miktarını arttırarak fonksiyonel gıda üretimine çeşitlilik kazandırma,

6. Epigenetik mekanizma ile eksprese olan gen sayısını artırma gibi olumlu sonuçlara ulaşılması mümkündür.

Ancak yukardaki olumlu etkilerin gerçekleşip gerçekleşmediğini test etmek için bu alandaki çalışmaların artırılması gereği vardır.

\section{Kaynaklar}

Al-Daraji HJ, Tahir AO (2014). Effect of L-carnitine supplementation on drake semen quality. South African Journal of Animal Science. 44(1): 18-25.

Anderson OS, Sant KE, Dolinoy DC (2012). Nutrition and epigenetics: an interplay of dietary methyl donors, one-carbon metabolism and DNA methylation. The Journal of Nutritional Biochemistry. 23(8): 853-859.

Ashwell C (2012). Genome-wide methylation analysis of chicken primordial germ cells. In: Plant and Animal Genome XX Conference, January 14-18, San Diego, USA.

Babacanoğlu E, Özkul Özelçam H (2013). Kanatlılarda maternal antioksidanların embriyo gelişimi için önemi. Yüzüncü Yıl Üniversitesi Tarım Bilimleri Dergisi. 23(1): 36-42.

Balaban M, Hill J (1971). Effects of thyroxine level and temperature manipulations upon the hatching of chick embryos (Gallus domesticus). Developmental Psychobiology. 4(1): 17-35.

Banks EA, Brozinick JT, Yaspelkis BB, Kang HY, Ivy JL (1992). Muscle glucose transport, GLUT-4 content, and degree of exercise training in obese Zucker rats. American Journal of PhysiologyEndocrinology And Metabolism. 263(5): E1015-E1020.

Biard C, Surai PF, Møller AP (2007). An analysis of pre-and post-hatching maternal effects mediated by carotenoids in the blue tit. Journal of Evolutionary Biology. 20(1): 326-339.

Blount JD, Houston DC, Møller AP (2000). Why egg yolk is yellow. Trends in Ecology \& Evolution. 15(2): 47-49.

Blount JD, Surai PF, Nager RG, Houston DC, Møller AP, Trewby ML, Kennedy MW (2002). Carotenoids and egg quality in the lesser black-backed gull Larus fucus: a supplemental feeding study of maternal effect. Proceedings of the Royal Society of London B: Biological Sciences. 269(1486): 29-36.

Bremer J (1983). Carnitine-metabolism and functions. Physiological Reviews. 63(4): 1420-1480.

Chen L, Qiu H, Zhu L, Qin S (2016). Selenium-enriched Saccharomyces cerevisiae improves growth performance, antioxidant status and selenoprotein gene expression in arbor acres broilers. Journal of Animal Physiology and Animal Nutrition. In press. 
Cheng TK, Coon CN, Hamre ML (1990). Effect of environmental stress on the ascorbic acid requirement of laying hens. Poultry Science. 69(5): 774-780.

Coşkun İ, Erener G, Şahin A, Karadavut U, Altop A, Okur AA (2014). Impacts of in ovo feeding of DLmethionine on hatchability and chick weight. Turkish Journal of Agriculture-Food Science and Technology. 2(1): 47-50.

Cozzi R, Ricordy R, Bartolini F, Ramadori L, Perticone P, De Salvia R (1995). Taurine and ellagic acid: Two differently-acting natural antioxidants. Environmental and Molecular Mutagenesis. 26(3): 248-254.

Çiftci İ, Tüzün CG, Vadiei M (2011). Broyler ve hindilerde yumurta içi (In Ovo) besleme uygulamalarının geliştirilmesi, Ankara Üniversitesi Bilimsel Araştırma Projeleri, Ankara.

Enting H, Boersma WJA, Cornelissen FBWJ, Van Winden SCL, Verstegen MWA, Van Der Aar PJ (2007). The effect of low-density broiler breeders diets on performance and immune status of their offspring. Poultry Science. 86(2): 282-290.

Ferket PR (2012). Embryo epigenomic response to breeder management and nutrition. In: XXIV World's Poultry Congress, 5-9 August 2012, Salvador-Bahia-Brazil, pp. 1-11.

Foye OT, Uni Z, Ferket PR (2006). Effect of in ovo feeding egg white protein, $\beta$-hydroxy- $\beta$-methyl butyrate, and carbohydrates on glycogen status and neonatal growth of turkeys. Poultry Science. 85: $1185-1192$.

Freeman BM (1967). Effect of stress on the ascorbic acid content of the adrenal gland of Gallus domesticus. Comparative Biochemistry and Physiology. 23(1): 303-305.

Friso S, Choi SW, Girelli D, Mason JB, Dolnikowski GG, Bagley PJ, Olivieri O, Jacques PF, Rosenberg $\mathrm{IH}$, Corrocher R, Selhub J (2002). A commonmutation in the 5, 10-methylene tetra hydrofolate reductase gene affects genomic DNA methylation through an interaction with folate status. Proceedings of the National Academy of Sciences. 99(8): 5606-5611.

Gaal T, Mezes M, Noble RC, Dixon J, Speake BK (1995). Development of antioxidant capacity in tissues of the chick embryo. Comparative Biochemistry and Physiology. 112(B): 711-716.

Geden CJ, Smith L, Long SJ, Rutz DA (1992). Rapid deterioration of searching behavior, host destruction, and fecundity of the parasitoid Muscidifurax raptor (Hymenoptera: Pteromalidae) in culture. Annals of the Entomological Society of America. 85(2): 179-187.

Grindstaff JL, Brodie ED, Ketterson ED (2003). Immune function across generations: integrating mechanism and evolutionary process in maternal antibody transmission. Proceedings of the Royal Society of London B: Biological Sciences. 270(1531): 2309-2319.

Halliwell B (1994). Free radicals and antioxidants: A personal view. Nutrition Reviews. 52: 253-265.

Halliwell, B. and Gutteridge, J.M.C. (1999). Free Radicals in Biology and Medicine. Third Edition. Oxford University Press, Oxford

Hasselquist D, Nilsson JA (2009). Maternal transfer of antibodies in vertebrates: trans-generational effects on offspring immunity. Philosophical Transactions of the Royal Society of London B: Biological Sciences. 364(1513): 51-60.

Hossain SM, Barreto SL, Bertechini AG, Rios AM, Silva CG (1998). Influence of dietary Vitamin E level on egg production of broiler breeders, and on the growth and immune response of progeny in comparison with the progeny from eggs injected with vitamin E. Animal Feed Science and Technology. 73(3): 307-317.

İzmirli M, Tufan T, Alptekin D (2012). DNA metilasyonu. Arşiv Kaynak Tarama Dergisi, 21(4): 274-282.

Jaeschke H (1995). Mechanisms of oxidant stress-induced acute tissue injury. Experimental Biology and Medicine. 209(2): 104-111.

Kaati G, Bygren LO, Edvinsson S (2002). Cardiovascular and diabetes mortality determined by nutrition during parents' and grandparents' slow growth period. European Journal of Human Genetics. 10(11): 682-688.

Karadas F, Surai PF, Grammenidis E, Sparks NHC (2006). Effects of maternal dietary supplementation with three sources of carotenoids on the retinyl esters of egg yolk and developing quail liver. Comparative Biochemistry and Physiology Part A: Molecular \& Integrative Physiology. 140(4): 430-435.

Lopez G, Leeson S (1994). Egg weigt and offspring performance of older broiler breeders fed low-protein diets. The Journal of Applied Poultry Research. 3(2): 167-170.

Macalintal LM (2012). In ovo Selenium (Se) Injection of Incubating Chicken Eggs: Effects on Embryo Viability, Tissue Se Concentration, Lipid Peroxidation, Immune Response and Post Hatch Development (Doktora tezi). University of Kentucky, College of Agriculture, Kentucy, ABD. 
Maldjian A, Cristofori C, Noble RC, Speake BK (1996). The fatty acid composition of brain phospholipids from chicken and duck embryos. Comparative Biochemistry and Physiology. 115 (B): 153-158.

McDowell LR (1989). Comparative aspects to human nutrition. Vitamin C, A and E. Vitamins in Animal Nutrition. Academic Press. London. 93-131.

Miguel-Carrasco JL, Monserrat MT, Mate A, Vázquez CM (2010). Comparative effects of captopril and 1carnitine on blood pressure and antioxidant enzyme gene expression in the heart of spontaneously hypertensive rats. European journal of pharmacology. 632 (1): 65-72.

Noble RC, Cocchi M (1990). Lipid metabolism in the neonatal chicken. Progress in Lipid Research. 29: 107-140.

Noble RC, Ogunyemi D (1989). Lipid changes in the residual yolk and liver of the chick immediately after hatching. Neonatology. 56(4): 228-236.

Noble R, Cocchi M, Bath HM (1993). $\alpha$-Tocopherol absorption and polyunsaturated fatty acid metabolism in the developing chick embryo. British Poultry Science. 34: 815-818.

Nowaczewski S, Kontecka H, Krystianiak S (2012). Effect of in ovo injection of vitamin C during incubation on hatchability of chickens and ducks. Folia Biologica. 60(1-2): 93-97.

Noy Y, Sklan D (2001). Yolk and exogenous feed utilization in the posthatch chick. Poultry Science. 80(10): 1490-1495.

Oso AO, Fafiolu AO, Adeleke MA, Ladokun OA, Sobayo RA, Jegede AV, Peters SO, Oyebamiji OA, Akinsola J (2014). Effect of dosage and application mode of 1-carnitine on plasma lipid and egg-yolk cholesterol of turkeys, hatchability of eggs and post-hatch growth of their offsprings. Journal of Animal Physiology and Animal Nutrition. 98(4): 766-774.

Pack M (1996). Ideal protein in broilers. Poultry International. 54-64.

Peebles ED, Doyle SM, PanskyT, Gerard PD, Latour MA, Boyle CR, Smith TW (1999). Effects of breeder age and dietary fat on subsequent broiler performance. 2. Slaughter yield. Poultry Science. 78(4): 512-515.

Pierce JL, Ao T, Xiao R, Brennan K, Edens FW (2016). Nutrigenomics: Implications for requirements for vitamins and antioxidants. http://www.thepoultryfederation.com/public/userfiles/files/15\%20Tue\%20-\%20James\%20Pierce\%20-\%20Nutrigenomics\%20\&\%20Vitamins.pdf. （Erişim tarihi: 07.04.2016).

Porter NA, Caldwell SE, Mills KA (1995). Mechanisms of free radical oxidation of unsaturated lipids. Lipids. 30: 277-290.

Pray LA (2004). Epigenetics: Genome, meet your environment: as the evidence for epigenetics, researchers reacquire a taste for Lamarckism. The Scientist. 18(13): 14-20.

Rabie MH, Ismail FSA, Ahmed AAS (2015). Effect of in ovo injection of lL-carnitine at different incubational ages on egg hatchability in broiler breeders and post-hatch performance. Asian Journal of Animal and Veterinary Advances. 10(12): 875-884.

Rebouche CJ (1992). Carnitine function and requirements during the life cycle. The FASEB Journal. 6(15): 3379-3386.

Redmond HP, Wang JH, Bouchier-Hayes D (1996). Taurine attenuates nitric oxide and reactive oxygen intermediate dependent hepatocyte injury. Archives of Surgery. 131(12), 1280-1288.

Romanoff AL (1960). The avian embryo. Structural and functional development. The Avian Embriyo, 1305.

Rubolini M, Possenti CD, Colombo G, Romano M, Caprioli M, Dalle-Donne I, Rubolini D, Karadas F, Milzani A, Saino N (2016). Yolk Vitamin E Positively Affects Early-life Growth and Oxidative Status in The Yellow-legged Gull. In press.

Sahin N, Tuzcu M, Orhan C, Onderci M, Eroksuz Y, Sahin K (2009). The effects of vitamin C and E supplementation on heat shock protein 70 response of ovary and brain in heat-stressed quail. British Poultry Science. 50(2): 259-265.

Sahin K, Sahin N, Kucuk O (2003). Effects of chromium, and ascorbic acid supplementation on growth, carcass traits, serum metabolites, and antioxidant status of broiler chickens reared at a high ambient temperature (32 C). Nutrition Research. 23(2): 225-238.

Saito K, Jin DH, Ogawa T, Muramoto K, Hatakeyama E, Yasuhara T, Nokihara K (2003). Antioxidative properties of tripeptide libraries prepared by the combinatorial chemistry. J. Agric. Food Chem. 51: 3668-3674.

Sarmadi BH, Ismail A (2010). Antioxidative peptides from food proteins: a review. Peptides. 31(10): 19491956.

Selim SA, Gaafar KM, El-ballal SS (2012). Influence of in-ovo administration with vitamin E and ascorbic acid on the performance of Muscovy ducks. Emirates Journal of Food and Agric. 24(3): 264-271. 
Sharma JM, Burmester BR (1982). Resistance of Marek's disease at hatching in chickens vaccinated as embryos with the turkey herpesvirus. Avian Diseases. 26(1): 134-149.

Sharma JM, Lee LF, Wakenell PS (1984). Comparative viral, immunologic, and pathologic responses of chickens inoculated with herpesvirus of turkeys as embryos or at hatch. American Journal of Veterinary Research. 45(8): 1619-1623.

Shenstone FS (1968). The gross composition, chemistry and physico-chemical basis of orgazation of the yolk and white, pp. 26-58, In: Egg Quality: A study of Hen's Egg, Horton-Smith C. and Amoroso EC (eds), Cornell University, New York.

Stock MK, Metcalfe J (1987). Modulation of growth and metabolism of the chick embryo by a brief (72-hr) change in oxygen availability. Journal of Experimental Zoology. 1: 351-356.

Surai PF (2002). Natural Antioxidants in Avian Nutrition and Reproduction. Nottingham University Press, Nottingham.

Surai PF, Fisinin VI, Karadas F (2016). Antioxidant systems in chick embryo development. Part 1. vitamin e, carotenoids and selenium. Animal Nutrition. 2(1): 1-11.

Surai PF, Karadas F, Pappas AC, Sparks NHC (2006). Effect of organic selenium in quail diet on its accumulation in tissues and transfer to the progeny. British Poultry Science. 47(1): 65-72.

Surai PF, Noble RC, Speake BK (1996). Tissue-specific differences in antioxidant distribution and susceptibility to lipid peroxidation during development of the chick embryo. Biochimica et Biophysica Acta. 1304: 1-10.

Sykes AH (1979). Vitamin C for poultry: some recent research. Roche Information Service. Animal Nutrition Department.

Triyuwanta LC, Nys Y (1992). Dietary phosporus and food allowance of dwarf breeders affect reproductive performance of hens and bone development of their progeny. British Poultry Sci. 33(2): 363-379.

Uni Z (2003). Methods for early nutrition an their potential. In: 14th Eur. Symp. Poultry. August, Norway.

Uni Z, Ferket PR (2003). Enhancement of development of oviparous species by in ovo feding. US patent number 6,592,878. Issued: Jul 15, 2003.

Wang FR, Dong XF, Tong JM, Zhang XM, Zhang Q, Wu YY (2009). Effects of dietary taurine supplementation on growth performance and immune status in growing Japanese quail (Coturnix coturnix japonica). Poultry science. 88(7): 1394-1398.

Waterland RA, Jirtle RL (2003). Transposable elements: targets for early nutritional effects on epigenetic gene regulation. Molecular and Cellular Biology. 23(15): 5293-5300.

Weaver ICG (2007). Epigenetic programming by maternal behavior and pharmacological intervention nature versus nurture: Let's call the whole thing off. Epigenetics. 2(1): 22-28.

Weinhold B (2006). Epigenetics: thescience of chance. Enviromental Health Perspect. 114(A): 160-167.

Wilson JX (1990). Regulation of ascorbic acid concentration inembryonic chick brain. Developmental Biology. 139: 292-298.

Yu BP (1994). Cellular defences against damage from reactive oxygen species. Physiological Reviews. 74: 139-162.

Zhang YY, Shan AS, Li F, Hu JW, Wang LS, Li YH, Cheng BJ, Bi CP (2011). Effect of maternal feed restriction on serum lipid metabolism during embryo period. Scientia Agricultura Sinica. 44: 40884095 . 